\title{
RANCANG ULANG RANTAI PASOK BAHAN BAKU UNTUK INDUSTRI MINUMAN SARI BUAH DI PASAR HOREKA STUDI KASUS PT. AMANAH PRIMA INDONESIA TANGERANG
}

\author{
Wanto Sarwoko \\ Dosen Fakultas Teknik Prodi Teknik Industri Universitas Pamulang \\ Dosen00927@unpam.ac.id
}

\begin{abstract}
ABSTRAK
Tujuan penelitian ini adalah mengetahui proses pengadaan bahan baku di PT.Amanah Prima Indonesia. dan mengetahui faktor-faktor yang mempengaruhi keterlambatan pengadaan bahan baku karena terhambat musim panen. Untuk mendapat hasil yang baik dan optimal, untuk itu penggunaan Metode Supply Chain bisa diterapkan untuk membatu proses pengadaan bahan. Peningkatan pembelian pada saat panen sebanyak 34\% tetapi terjadi efesiensi biaya sebanyak 3\%. Dengan pembelian dalam jumlah besar dapat menghemat cost dan proses produksi serta penerapan sewa gudang lebih murah dibanding harus membangun gudang sendiri karena penggunaannya hanya pada saat panen.
\end{abstract}

Kata kunci : Metode Supply Chain Managemen

\section{PENDAHULUAN}

Sejalan dengan perkembangan masyarakat pada saat ini dan meningkatnya tarap hidup masyarakat, serta kesadaran akan mengkonsumsi buah untuk kesehatan, dengan kesibukan yang meningkat dan gaya hidup masyarakat pada umumnya cendrung lebih senang meminum jus karena lebih praktis dari pada makan buah dan waktu lebih luang untuk mengkonsumsi buah asli. Minuman jus menjadi salah satu alternatif pilihan, karena di dalam minuman jus bisa diperoleh sumber cairan,sumber vitamin,sumber mineral, karbohidrat dengan indeks glikemik rendah dan sumber senyawa fitolimia. Minuman jus juga menjadi sumber serat yang bermanfaat untuk proses pencernaan,mengikat racun dan memberikan rasa kenyang, hal ini juga sangat baik bagi yang sedang melalukan diet.

Melihat manfaat yang sedemikian besar dari mengkonsumsi minuman sari buah dan sayursayuran, tentunya memberikan peluang tersendiri bagi produsen minuman sari buah dan sayursayuran yang dibuat oleh pabrik.

Indonesia dengan jumlah penduduknya yang cukup besar saat ini sekitar 252 juta jiwa pada tahun 2014, merupakan pasar yang sangat pontesial untuk minuman jus siap minum yang dibuat secara pabrikan.
Berikut adalah Grafik pertumbuhan penduduk Indonesia sebagai berikut:

\section{Grafik Peningkatan Penduduk}

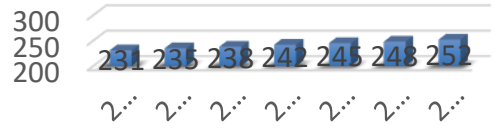

Gambar 1.1. Grafik Pertumbuhan Penduduk Indonesia

Dari tabel 1.1 perkembangan penduduk indonesia setiap tahun terus meningkat, dari peningkatan pertumbuhan penduduk dipastikan meningkat pula kebutuhan konsusmsi. Dengan meningkatnya penduduk menjadi peluang bisnis setiap pelaku bisnis.

Kondisi perekonomian Indonesia selama ini turut mendorong menciptakan pasar yang baik, walaupun sempat terhambat sejak terjadinya kerisis ekonomi yang berkepanjangan.

PT. Amanah Prima Indonesia adalah sebuah perusahaan industri minuman sari buah dalam kemasan yang menghasilkan berbagai jenis rasa buah-buahan, yang produknya dipasarkan di dalam negeri dengan konsumen utama adalah hotel, restaurant, cafe dan catering (food 
service). Sebagai industri yang memproduksi minuman sari buah, dalam meningkatkan mutu PT. Amanah Prima Indonesia mempunyai beberapa jenis variasi produk dan jenis bahan baku. Banyaknya jenis bahan baku dan barang jadi tersebut membuat pengaturan persediaan bahan baku dan barang jadi menjadi sangat penting untuk efisiensi nilai dan biaya persediaan. Meskipun mempunyai departemen yang bertugas mengontrol persediaan namun sering kali persediaan tidak berada pada level yang telah ditetapkan sebelumnya.

Pasar minuman jus siap minum di dalam negeri kemungkinan terjadi peningkatkan pada tahun-tahun mendatang, seiring dengan meningkatnya jumlah penduduk dan semakin membaiknya perekonomian Indonesia. Ada kecenderungan semakin membaik kondisi ekonomi masyarakat akan meningkat mobilitas dan kegiatan penduduk di luar rumah semakin tinggi, sehingga mendororng terjadinya perubahan pola dan kebiasaan masyarakat dalam mengkonsumsi sesuatu produk ke arah produk yang lebih praktis.

Untuk mengetahui proyeksi volume pasar minuman jus siap minum di Indonesia pada tahun-tahun mendatang, maka sebagai dasar proyeksinya dipakai suatu pendekatan yang sangat sederhana, yaitu dengan memperkirakan penggunaan rata-rata pertahun produksi jus siap minum dengan menggunakan data tahun sebelumnya. Jika dilihat dari kebutuhan komsumen produk minuman memiliki prospek yang cukup bagus di Indonesia. Berikut tabel pertumbuhan produk minuman ringan dapat dilihat pada tabel 1.1 berikut:

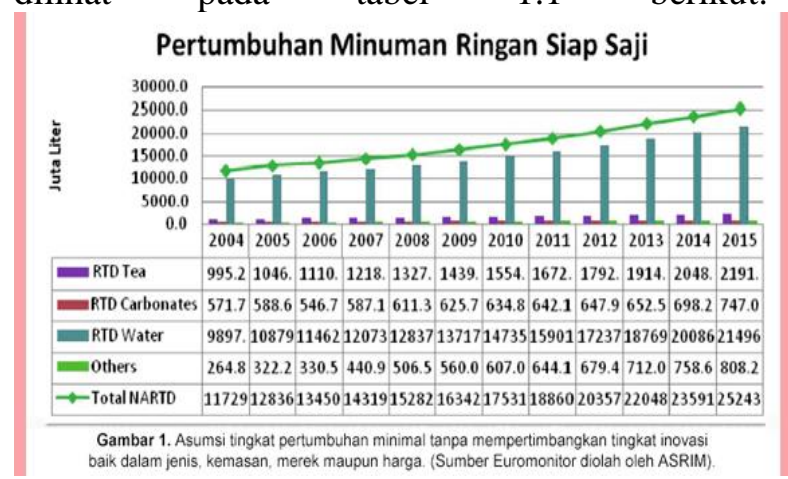

(Sumber: Badan Pusat Statistik, 2012)

Dari tabel 1.1. terlihat pertumbuhan minuman sari bauah yang sangat baik. Menurut Asosiasi Industri Minuman Ringan (ASRINI). Perkembangan industri minuman sangat menjanjikan sampai saat ini sudah ada 35 pabrik minuman siap saji dengan 60 merek yang berbeda. Perusahan-perusahan yang memproduksi minuman sari buah.

terdapat bebapa produsen minuman sari buah, berdasarkann data yang ada jumlah produsen produk minumna sari buah yang semakin banyak menjadi daya saing bagi para pemain produk minuman sari buah. Kesempatan ini dapat dimanfaatkan karena Indonesia sebenarnya penghasil buah-buahan tropis yang cukup baik yang dikembangkan, didukung dengan letak geografis negara Indonesia yang menunjang tumbuh kembang tanaman holtikutura dengan baik, hal ini merupakan salah satu penunjang faktor yang sangat berperan dalam pendirian pabrik minuman sari buah (jus).

Potensi market yang sangat luas terlihat dari pertumbuhan hotel, restauran dan kafe yang cukup baik setiap tahun ke tahun, saat ini jus TOZA hanya dipasarkan pada sektor HOREKA. Dimana perusahan mengatur kedatangan pasokan bahan baku, disesuaikan kebutuhan perusahan. Strategi juga dibutuhkan untuk mengatsi fluktuatif permintaan yang terjadi. Ketersedia bahan juga meningkatkan penjualan produk kepada konsumen.

Tabel 1.2 Potesin market produk toza

\begin{tabular}{|c|c|c|c|c|c|c|c|c|c|}
\hline \multirow{3}{*}{ AREA } & \multicolumn{8}{|c|}{ TARGET POTENSI PASAR HOTEL DAN MARKET SHARE TOZA 2015} & \multirow{3}{*}{$\%$} \\
\hline & \multicolumn{2}{|c|}{ 5STAR } & \multicolumn{2}{|c|}{ 4 STAR } & \multicolumn{2}{|c|}{ 3STAR } & \multicolumn{2}{|c|}{ TOTAL } & \\
\hline & TOTAL & TOZA & TOTAL & TOZA & TOTAL & TOZA & TOTAL & TOZA & \\
\hline JAKARTA & 36 & 22 & 109 & 67 & 137 & 74 & 282 & 163 & $58 \%$ \\
\hline BANDUNG & 10 & 4 & 26 & 13 & 51 & 31 & 87 & 48 & $55 \%$ \\
\hline JOGJAKARTA & 12 & 5 & 33 & 22 & 57 & 29 & 102 & 56 & $55 \%$ \\
\hline SEMARANG & 5 & 3 & 9 & 8 & 37 & 22 & 51 & 33 & $65 \%$ \\
\hline SURABAYA & 8 & 6 & 24 & 15 & 23 & 12 & 55 & 33 & $60 \%$ \\
\hline BALI & 56 & 18 & 83 & 46 & 215 & 154 & 354 & 218 & $62 \%$ \\
\hline TOTAL & 127 & 58 & 284 & 171 & 520 & 322 & 931 & 551 & $59 \%$ \\
\hline Market share & \multicolumn{2}{|c|}{$46 \%$} & \multicolumn{2}{|c|}{$60 \%$} & \multicolumn{2}{|c|}{$62 \%$} & \multicolumn{2}{|c|}{$59 \%$} & \\
\hline
\end{tabular}

(Sumber:PT.Amanah Prima Indonesia)

Dari tabel 1.2 terlihat masih besar peluang market yang bisa dipenuhi dan terbuka luas kesempatan untuk mencapai hasil yang lebih besar sehingga daya saing perusahaan menjadi lebih baik. PT. Amanah Prima Indonesia tidak dapat memenuhi supply secara optimal dikarenakan ada bahan baku yang sifatnya musiman sehingga tidak dapat memenuhi kebutuhan produksi dan mengoptimalkan potensi market dari masing-masing kota tersebut diatas.

Demikian pula sebaliknya, persediaan bahan baku yang terlalu kecil dalam perusahaan akan 
mengakibatkan kemacetan dalam proses produksi,sehingga perusahaan akan mengalami kerugian. Dari uraian di atas, maka dapat diperoleh beberapa rumusan masalah yaitu:

1. Untuk mengetahui pengadaan bahan baku perusahan saat ini ?

2. Untuk mengetahui faktot-faktor yang mengakibatkan keterlambatan pasokan bahan baku?

3. Bagaimana rancangan ulang rantai pasok yang baik untuk produksi minuman sari buah?

\section{DASAR TEORI}

\section{A.Pengertian Rantai Pasok}

Manajemen rantai pasok adalah proses pengadaan bahan baku, bahan setengan jadi yang langsung didapat dari sumber pemasok sedangkan produk jadinya langsung didistribusikan ke komsumen. Sasarannya untuk membangun sebuah pelayanan kepada pelanggan.Tujuan utama dari rantai pasok adalah penyerahan atau pengiriman produk secara tepat waktu demi memuaskan konsumen Usaha bagi manajemen rantai pasok yang efektif adalah menjadikan para pemasok sebagai rekan kerja dalam strategi perusahan

Penegertian Supply Chain Management adalaha pengelolaan dan pengawasan rantai siklus, mulai dari aliran material/barang mentah,pembayaran,informasi dan pemasok ke produsen ke pada perusahan atau pun komsumen - Rantai ini juga merupakan jaringan dari berbagai organisasi yang saling berhubungan dan mempunyai tujuan yang sama, yaitu sebaik mungkin menyelenggarakan pengadaan atau barang tersebut, istilah supply chain meliputi juga proses perubahan barang tersebut, misalnya dari barang mentah menjadi barang jadi.

\section{B.Konsep Manajemen Rantai Pasok (Supply Chain Management)}

Manajemen rantai pasok (supply chain management) merupakan isu yang sedang hangat dibicarakan saat ini. Sebagai dasar untuk memahami mengenai bagaimana manajemen rantai pasok dilakukan, sebelumnya akan dijelaskan definisi manajemen rantai pasok.

\section{C.Dimensi Pengadaan}

Pengadaan adalah bagian dari supply chain management yang secara sistematik dan strategis memproses pengadaan barang dan jasa mulai dari sumber barang sampai dengan tempat tujuan sumber dan tempat, untuk memenuhi kebutuhan pelanggan.(Willem Siahaya). Dari dimensi pengadaan terdapat 5 indikator sebagai berikut:

1. Seleksi Pemasok

2. Menganalisa kinerja pemasok

3. Melakukan pembelanjaan bahan baku dan komponen

4. Pengawasan pemasaok

5. Bekerjasama dengan para supplier

\section{D.Analisa Faktor}

Analisis faktor adalah suatu teknik statistik multivariate yang digunakan untuk mengurangi dan meringkas suatu variable terikat dan saling berketergantungan. Hubungan ketergantungan antara satu variable dengan yang lain yang akan diuji untuk diidentifikasi dimensi atau faktornya. penelitian Ex-post facto berjalan dengan cara menentukan akibat lalu menemukan sebab. Populasi dalam penelitian ini adalah staf-staf perusahan dari jenjang leader sampai dengan manager dan sebagian para suplier bahan baku yang tersudah bekerja sama selama ini dengan perusahaan.

\section{III.METODE PENELITIAN}

\section{A.Pengumpulan Data.}

Berikut Data hasil pengolahan buah segar menjadi puree pada tahun 2014 sampai tahun 2015 dapat dilihat pada Tabel 1.3 berikut:

Tabel 1.3 Data Pengolahan Bahan Baku Buah Segar Menjadi Puree

\begin{tabular}{|c|c|c|c|c|}
\hline \multirow{2}{*}{ No } & Nama & \multirow{2}{*}{ Produk } & Satuan & \multicolumn{2}{|c|}{ Tahun } \\
\cline { 4 - 5 } 01 & $\begin{array}{c}\text { Apel } \\
\text { Puree }\end{array}$ & $\mathrm{Kg}$ & 4.710 & 4.398 \\
\hline 02 & $\begin{array}{c}\text { Nanas } \\
\text { Puree }\end{array}$ & $\mathrm{Kg}$ & 6.864 & 7.284 \\
\hline 03 & $\begin{array}{c}\text { Jambu } \\
\text { Puree }\end{array}$ & $\mathrm{Kg}$ & 90.825 & 91.094 \\
\hline 04 & $\begin{array}{c}\text { Sirsak } \\
\text { Puree }\end{array}$ & $\mathrm{Kg}$ & 8.485 & 11.542 \\
\hline 05 & $\begin{array}{c}\text { Strowberi } \\
\text { Puree }\end{array}$ & $\mathrm{Kg}$ & 3.324 & 4.424 \\
\hline 06 & Kiwi & $\mathrm{Kg}$ & 2.735 & 3.219 \\
\hline
\end{tabular}




\begin{tabular}{|l|c|c|c|c|} 
& Puree & & & \\
\hline 07 & $\begin{array}{c}\text { Belimbing } \\
\text { Puree }\end{array}$ & Kg & 3.138 & 2.820 \\
\hline
\end{tabular}

(Sumber: PT Amanah Prima Indonesia)

Dari tabel 1.3 dapat dilihat ada perbedaan antara pembelian buah segar dan hasil puree yang didapat setelah selesai diproduksi. Dari pemerosesan buah-buah segar menjadi puree tidak semua buah menjadi puree, untuk kulit dan ampas dibuang sehingga yang diambil hanya sarinya saja, hasil buah biasanya disebut dengan yeld. Dengan mengetahui yeld tesebut maka akan diketahui berapa harga puree setelah diolah. Berikut data pemakaian bahan baku puree selama tahun 2014 sampai Tahun 2015 dapat dilihat pada tabel 1.4

Tabel 1.4 Data Pemakaian Bahan Baku Puree (Sumber PT. Amanah Prima Indonesia)

\begin{tabular}{|c|c|c|c|c|}
\hline \multirow{2}{*}{ No } & Nama & \multirow{2}{*}{ Satuan } & \multicolumn{2}{|c|}{ Tahun } \\
\cline { 4 - 5 } 01 & Produk & & 2014 & 2015 \\
\hline 02 & $\begin{array}{c}\text { Apel } \\
\text { Puree }\end{array}$ & $\mathrm{Kg}$ & 4.374 & 4.122 \\
\hline 02 & $\begin{array}{c}\text { Nanas } \\
\text { Puree }\end{array}$ & $\mathrm{Kg}$ & 6.390 & 6.903 \\
\hline 03 & $\begin{array}{c}\text { Jambu } \\
\text { Puree }\end{array}$ & $\mathrm{Kg}$ & 88.781 & 91.936 \\
\hline 04 & $\begin{array}{c}\text { Sirsak } \\
\text { Puree }\end{array}$ & $\mathrm{Kg}$ & 10.241 & 12.067 \\
\hline 05 & $\begin{array}{c}\text { Strowberi } \\
\text { Puree }\end{array}$ & $\mathrm{Kg}$ & 4.415 & 4.749 \\
\hline 06 & $\begin{array}{c}\text { Kiwi } \\
\text { Puree }\end{array}$ & $\mathrm{Kg}$ & 2.725 & 3.118 \\
\hline 07 & $\begin{array}{c}\text { Belimbing } \\
\text { Puree }\end{array}$ & $\mathrm{Kg}$ & 2.855 & 2.947 \\
\hline
\end{tabular}

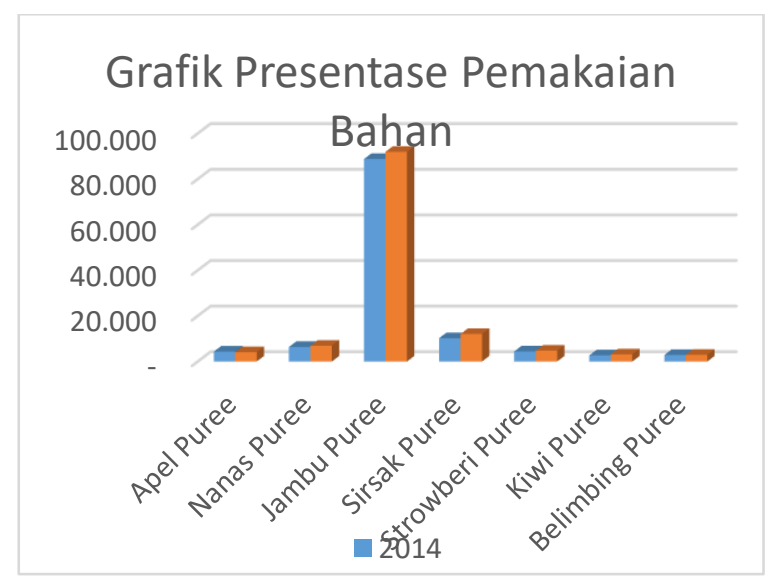

Gambar 1.2. Grafik Pemakaian Bahan Baku Puree Tahun 2014 sampai 2015
Data pada Tabel 1.4 Terlihat peningkatan pemakaian bahan baku puree pada semua bahan.Tetapi dari semua bahan terlihat yang sangat menonjol pemakaiannya adalah pada bahan baku puree jambu yang pemakaiannya mencapai $72 \%$ dari dari semua bahan yang dipakai untuk produksi jus mengalahkan pemakaian bahan baku yang lain

\section{IV.HASIL DAN PEMBAHASAN}

\section{A.Variabel Pengadaan}

Dari hasil pengolahan data ditemukan ada 10 faktor yang membentuk variabel kondisi penerimaan barang dari suplier dapat dilihat berikut:

Tabel. 1.5 Rotated Componen Matrix

\begin{tabular}{|c|c|c|c|}
\hline & \multicolumn{3}{|c|}{ Component } \\
\hline & 1 & 2 & 3 \\
\hline PG1 &,- 001 &, 064 &, 557 \\
\hline PG2 &, 375 &,- 016 &, 459 \\
\hline$P G 3$ &, 327 &,- 165 &,- 091 \\
\hline$P G 4$ &, 669 &, 117 &,- 168 \\
\hline PG5 &, 810 &,- 012 & ,302 \\
\hline PGG &, 798 &, 220 &, 294 \\
\hline$P G 7$ &, 529 & ,O>7 &, 517 \\
\hline$P G 8$ &,- 048 &, 017 &, 811 \\
\hline PG9 & ,029 &, 902 &, 091 \\
\hline $\begin{array}{l}P G 1 \\
O\end{array}$ &, 057 &, 920 &,- 004 \\
\hline
\end{tabular}

Penentuan variabel masuk faktor mana ditentukan dengan melihat nilai loading factor sebesar 0,6. Pada tabel diatas dapat diuraikan anggota masing-masing faktor sebagai berikut: Faktor 1 terdiri dari indikator-indikator berikut:

a. $\mathrm{PG} 4=$ Kurangnya kordinasi terhadap supplier

b. PG5 = Pembelian bahan baku tidak dapat dilakukan secara parsial

c. $\quad$ PG6 = Selalu tidak ada kepastian setiap stok yang akan dibeli

Dari 3 faktor utama dalam variabel Pengadaan tersebut, dapat dikatakan sebagai faktor yang mempengaruhi, sehingga faktorfaktor yang mempengaruhi keterlambatan pasokan bahan baku harus memperhatikan faktor yang dianggap penting oleh responden, sehingga Keterlambatan bahan baku dapat diminimalisir dalam kedatangannya.

\section{B.Variabel Perencanaan Dan Pengendalian}

Dari hasil pengolahan data ditemukan ada 10 faktor yang membentuk variabel Perencanaan dan pengadaan. Untuk lebih jelasnya dapat dilihat pada tabel berikut: 
Tabel. 1.6. Rotated Componen Matrix

\begin{tabular}{|l|r|r|r|}
\hline & \multicolumn{3}{|c|}{ Component } \\
\cline { 2 - 4 } & \multicolumn{1}{|c|}{1} & \multicolumn{1}{c|}{2} & \multicolumn{1}{c|}{3} \\
\hline PP1 &, 598 &, 160 &,- 017 \\
PP2 &, 264 &, 164 &,- 783 \\
PP3 &, 228 &, 210 &, 781 \\
PP5 &, 533 &,- 037 &,- 037 \\
PP6 &, 822 &,- 099 &,- 047 \\
PP7 &, 819 &, 104 &, 064 \\
PP8 &, 725 &, 094 &, 012 \\
PP9 &, 064 &, 970 &,- 015 \\
PP1 &, 041 &, 971 &, 057 \\
0 & & \\
\hline
\end{tabular}

Penentuan variabel masuk faktor mana ditentukan dengan melihat nilai loading factor sebesar 0,6. Pada tabel diatas dapat diuraikan anggota masing-masing faktor sebagai berikut:

Faktor 1 terdiri dari indikator-indikator berikut:

a. PP6 = Pengelompokan produksi berdasarkan jenis buah

b. PP7 = Produksi dibuat berdasarkan satuan satuan tertentu

c. $\mathrm{PP} 8=$ Mempunyai rencana produksi yang tak akurat

Dari 3 faktor utama dalam variabel Perencanaan dan proses tersebut, dapat dikatakan sebagai faktor yang mempengaruhi, Proses produksi terhambat dan tidak sesuai yang direncanakan sehingga bahan baku harus memperhatikan faktor yang dianggap penting oleh responden, sehingga hasil Keterlambatan bahan baku dapat diminimalisir dalam kedatangannya.

\section{C.Variabel Operasi Produksi}

Dari hasil pengolahan data ditemukan ada 10 faktor yang membentuk variabel Operasi Produksi. Untuk lebih jelasnya dapat dilihat pada tabel berikut:
Tabel. 1.7. Rotated Componen Matrix

\begin{tabular}{|l|r|r|r}
\hline & \multicolumn{3}{|c}{ Component } \\
\cline { 2 - 4 } & 1 & 2 & \multicolumn{1}{c}{3} \\
\hline OP1 &, 802 &, 003 &, 07 \\
OP2 &, 888 &, 082 &, 15 \\
OP3 &,- 018 &, 467 &,- 11 \\
OP4 &, 795 &, 096 &, $0 \subseteq$ \\
OP5 &, 593 &, 412 &, $1 \mathrm{C}$ \\
OP6 &, 159 &, 852 &, 21 \\
OP7 &, 251 &, 828 &, $2 \pm$ \\
OP8 &, 064 &, 661 &, 57 \\
OP9 &, 029 &, 345 &, 81 \\
OP10 &, 318 &,- 153 &, 81 \\
\hline
\end{tabular}

Penentuan variabel masuk faktor mana ditentukan dengan melihat nilai loading factor sebesar 0,6. Pada tabel diatas dapat diuraikan anggota masing-masing faktor sebagai berikut:

Faktor 1 terdiri dari indikator-indikator berikut:

a. $\mathrm{OP} 1=$ Produksi berjalan tidak sesuai perencanaan

b. $\mathrm{OP} 2=$ Proses produksi berjalan sesuai dengan standard operasional procedure

c. $\mathrm{OP} 4=$ Produksi berjalan dengan pengawasan yang lemah

Dari 3 faktor utama dalam variabel Operasi produksi tersebut, dapat dikatakan sebagai faktor yang mempengaruhi, keterlambatan pasokan bahan baku harus memperhatikan aspek yang dianggap penting oleh responden, sehingga hasil Keterlambatan bahan baku dapat diminimalisir dalam kedatangannya.

\section{D.Variabel Mekanisme Pengangkutan Barang dan Bahan Baku}

Dari hasil pengolahan data ditemukan ada 10 faktor yang membentuk variabel Mekanisme pengangkutan barang dan bahan baku. Untuk lebih jelasnya dapat dilihat pada tabel berikut:

Tabel. 1.8. Rotated Componen Matrix Rotated Component Matrix

\begin{tabular}{|l|r|r|r|}
\hline \multicolumn{3}{|c|}{ Rotated Component Matrixa } \\
\cline { 2 - 4 } & 1 & \multicolumn{3}{|c|}{ Component } \\
\hline MP1 &,- 110 &, 186 & \multicolumn{1}{c|}{, 851} \\
MP2 &,- 074 &, 068 &, 914 \\
MP4 &, 282 &,- 094 &, 779 \\
MP5 &, 835 &, 244 &, 041 \\
MP6 &, 904 &, 211 &,- 008 \\
MP7 &, 889 &, 209 &, 031 \\
MP8 &, 297 &, 736 &,- 134 \\
MP9 &, 104 &, 812 &,- 012 \\
MP10 &, 061 &, 881 &, 085 \\
\hline
\end{tabular}

Penentuan variabel masuk faktor mana ditentukan dengan melihat nilai loading factor sebesar 0,6. Pada tabel diatas dapat diuraikan anggota masing-masing faktor sebagai berikut:

Faktor 1 terdiri dari indikator-indikator berikut:

a. MP4= Mobilisasi supplier tidak sudah mendukung untuk aktifitas pengiriman bahan baku 
b. $\quad$ MG5 = Pengiriman selalu tepat waktu

c. MG6 = Estimasi kedatangan bahan baku sedikit

Dari 3 faktor utama dalam variabel Mekanisme pengangkutan barang dan bahan baku tersebut, dapat dikatakan sebagai faktor yang mempengaruhi, sehingga aspek keterlambatan pasokan bahan baku harus memperhatikan komponen yang dianggap penting oleh responden, sehingga hasil Keterlambatan bahan baku dapat diminimalisir dalam kedatangannya.

\section{E.Variabel Strategic Supplier Patnership}

Dari hasil pengolahan data ditemukan ada 10 faktor yang membentuk variabel Strategic Supplier Patnership. Untuk lebih jelasnya dapat dilihat pada tabel berikut:

Tabel. 1.9. Rotated Componen Matrix

\begin{tabular}{|l|r|r|r|}
\hline & \multicolumn{3}{|c|}{ Component } \\
\cline { 2 - 4 } & \multicolumn{1}{|c|}{1} & \multicolumn{1}{c|}{2} & \multicolumn{1}{c|}{3} \\
\hline SP1 &, 114 &,- 154 &, 849 \\
SP2 &, 157 &, 203 &, 850 \\
SP3 &, 742 &, 385 &, 025 \\
SP4 &, 927 &, 138 &, 156 \\
SP5 &, 893 &,- 086 &, 058 \\
SP6 &, 729 &, 351 &, 277 \\
SP7 &, 304 &, 788 &, 231 \\
SP8 &, 163 &, 888 &, 081 \\
SP9 &, 001 &, 622 &,- 333 \\
\hline
\end{tabular}

Penentuan variabel masuk faktor mana ditentukan dengan melihat nilai loading factor sebesar 0,6. Pada tabel diatas dapat diuraikan anggota masing-masing faktor sebagai berikut:

Faktor 1 terdiri dari indikator-indikator berikut:
a. SP3= Supplier terpengaruh terhadap jumlah pemesanan
b. $\mathrm{SP} 4$ = Jaminan kepastian pemesanan kembali kepada setiap suplier selalu ada masalah
c. $\mathrm{SP} 5=$ Kualitas bahan baku sudah tidak mempunyai standar yang disepakati

Dari 3 faktor utama dalam variabel Strategic Supplier Patnership tersebut, dapat dikatakan sebagai faktor yang mempengaruhi, keterlambatan pasokan bahan baku harus memperhatikan situasi yang dianggap penting oleh responden, sehingga hasil Keterlambatan bahan baku dapat diminimalisir dalam kedatangannya.

\section{KESIMPULAN}

1. Kondisi rantai pasok bahan baku perusahaan saat ini (sebelum rancang ulang) Gambar rantai pasok bahan baku diatas terlihat Pembelian buah jambu dari satu supplier dan sering mengalami kekurangan bahkan tidak bisa suplay, dengan kondisi suplay yang tidak teratur membuat biaya produksi menjadi mahal, ditambah lagi dengan masalah penyimpanan dan kapasitas gudang yang hanya dapat menampung hanya 17 ton sehingga pada saat musim panen tidak bisa membeli dalam kondisi banyak karena terkendala gudang sedangkan musim panen hanya dua kali dalam setahun. Hal ini sering mengakibatkan kekeurangan bahan baku khususnya pada saat tidak ada musim panen khususnya produk puree jambu.

2. Berdasarkan pembahasan analisa faktor, terdapat terdapat 4 faktor utama dalam variabel Strategic Supplier Patnership dapat dikatakan sebagai faktor yang mempengaruhi, sehingga faktor-faktor yang mempengaruhi keterlambatan pasokan bahan baku harus memperhatikan faktor yang dianggap penting oleh responden, sehingga hasil Keterlambatan bahan baku dapat diminimalisir dalam kedatangannya.

Adapun implementasinya adalah :

a. Supplier tidak terpengaruh terhadap jumlah pemesanan

b. Jaminan kepastian pemesanan kembali kepada setiap suplier selalu ada

c. Kualitas bahan baku sudah mempunyai standar yang disepakati

d. Supplier wajib mengirim bahan baku dengan kualitas sesuai kesepakatan

3. Kondisi rantai pasok setelah rancang ulang

Dari gambar diatas terlihat terjadi perubahan rancangan suplay yang awalnya hanya menggunakan satu supplier menjadi tiga supplier hal ini dilakukan untuk menampung bahan baku jambu biji pada saat panen raya. Pada saat panen buah jambu sangat bagus dan harganya pun sangat murah sehingga terjadi efisiensi terhadap 
$\begin{array}{lll}\text { pembelian sedangkan untuk } & \end{array}$ penyimpanan PT.Amanah Prima Indonesia selain mempunyai gudang sendiri juga melakukan penyewa gudang pendingin yang bekerjasama dengan pihak luar hal ini dilakukan untuk menyerap buah jambu biji pada saat panen. Dari perhitungan sewa gudang ternyata lebih murah sewa gudang dibandingkan dengan buat gudang atau beli bahan baku jambu biji pada saat tidak panen karena pada saat tidak panen harga biasa naik sampai $400 \%$ dan terkadang buah nya pun tidak ada sehingga sering terjadi kekurangan bahan baku sehingga produksi terhenti.

\section{DAFTAR PUSTAKA}

Anita Dewiyana Buntoro (2012) dalam penelitiannya yang berjudul:"Usulan penerapan Supply Chain Management dan Activity Based Costing yang Efektif pada PT. X

Apriyanti Ruganda Yuniar, Tesis "Analisa Manajemen Rantai Pasok Melon Di Kabuten Karang Anyar", Universitas Sebelas Maret,Surakarta 2012
Chopra, Sunil and Peter Meindl, 2004. Supply Chain Management Strategy, Planning, and Operation. Second Edition.

M Rhendria Dinawan (2010) dalam penelitian yang berjudul." Analisa Faktor-Faktor Yang Mempengaruhi Keputusan Pembelian.

Trina Fizzanty dan Kusnandar ( 2012) dalam penelitian yang berjudul: “ Pengelolaan Logistik Dalam Rantai Pasok Produk 